single organization. It then goes on to demolish claims which British steel makers have been making in their battle against nationalization: ". . . true price competition has never operated successfully in this or any other country". It must have come as a great relief to some members of the board to be able, at last, to admit it.

\section{How to import Chemicals}

REsEARCH workers, both in industry and universities, have been complaining about the difficulty of importing small chemical samples into this country. The samples are of compounds which are not manufactured here, and may be available only from a single firm abroad. Although they are given completely free by the manufacturers, and are clearly marked "For Scientific Purposes Only", they have, in certain cases, been subject to import duty. Even more annoying, delays in delivery are frequent; a box of samples that crosses the Atlantic in eight hours may take three weeks to reach the laboratory from London Airport.

The best way to be certain of the swift arrival of a shipment is to employ one of the freight agencies that handle goods at docks and airports. A laboratory will have to pay such an agent three or four pounds to have a case of samples sent through the customs, and put on the train. This sum may well be ten times the value of the chemicals, so that the privilege of receiving free gifts from American and European companies may cost a research team dear. Dr R. Schmutzler, of Loughborough University of Technology, has recently complained about the problem to the Ministers of Technology and Education. He tells of how he was forced to pay agency dues out of his own pocket; there was no provision for them in his research budget.

Those who try to do without the agencies find themselves at a disadvantage. Among other things, they are required to show that the rare chemicals they have ordered will be used only for research. The proof of this, Dr Schmutzler writes, is not easily demonstrated in letters to the customs or by appearance in person at the airport. Yet when the agencies handle the chemicals, no such rigorous investigation of the possibility of their misuse takes place. The customs will accept that drugs imported for laboratory research will be properly looked after only when the actual importing is done by an agency.

The agency will not, of course, question the motives of a university worker who orders a dangerous drug through them. The moral is therefore clear: research workers who are determined to supplement their salaries by selling drugs to swinging Londoners had better order through chemical import agencies. Only the honest man, insensitive to all insinuations of fraudulence, and disposed of a great deal of time, can handle imports of this kind for himself.

Dr Schmutzler goes on to compare the sympathetic attitude of the American authorities to the international traffic in valuable chemical samples, with the suspicion and lack of understanding shown by the customs over here. $\mathrm{He}$ and other frustrated research workers feel that it should surely be possible for them to obtain samples quickly, and without too much expense on the one hand, or trouble and even humiliation on the other.

\section{Loaves and Fishes}

Fon an organization with a budget of only four hundred thousand pounds, the White Fish Authority certainly appears exceptionally versatile. In its research report, published this month, the Authority describes a cockle harvester, which will enable fishermen to exploit sublittoral beds where the density of the mollusc population is low, and gives an account of fish rearing experiments in Scottish lochs, and in tanks in which the water is heated by the effluent of nuclear power stations. This latter experiment is of unusual interest. It has been possible to rear a small number of sole to a marketable size in only one year, a process which would take three years in natural conditions. Other projects include the development of fenders, so that fish can be transferred from one vessel to another at sea. The authority also concerns itself with the processing of caught fish from their initial superchilling at $28^{\circ} \mathrm{F}$. to their eventual appearance in specially concocted sausages and fish crisps.

As the report points out, most of the innovations in fishing techniques could have been produced fifty years ago. Conservatism, rather than lack of knowledge, prevented their development sooner. On the other hand, the authority is having to pioneer methods of basic research, in order to find out, for instance, how ships behave at sea in extreme conditions. The chairman of the research committee of the authority, Sir Fredrick Brundrett, has called-not for the first time - for a National Council of Marine Technology, saying that conditions in the fishing industry when the authority was founded had differed little from those obtaining in Galilee two thousand years ago. Perhaps a better comparison could have been drawn: even with the million pounds that Sir Fredrick wants for new research, the authority will be hard put to emulate certain achievements of those days. They did more with bread and fish then than make sausages out of them.

\section{More Aid for Visual Aids}

HARD on the heels of the newly formed National Council for Educational Technology, sponsored by the Department of Education and Science, comes the Industrial Council for Educational and Training Technology. This has been formed by four trade associations: the British Electrical and Allied Manufacturers' Association, the British Radio Equipment Manufacturers' Association, the Electronic Engineering Association, and the Scientific Instrument Manufacturers' Association. It has originally been the plan that ICETT should co-ordinate the production and use of technical aids in teaching, from machines to textbooks, but the formation of NCET will no doubt cause the Industrial Council to concentrate on the production of teaching aids, rather than their use. There have already been informal talks between the two organizations.

At present, ICETT is only qualified to work on behalf of manufacturers of hardware; discussions have been held with publishing and film associations. (Individual companies may not join the Council.) If ICETT can widen its interests to include both software and hardware, and if it can achieve close relations with NCET, we may hope to see more and better use of educational aids; this may become more and more important if the teacher shortage worsens. 